\title{
Evaluation of imazethapyr-induced DNA oxidative damage by alkaline Endo III- and Fpg-modified single-cell gel electrophoresis assay in Hypsiboas pulchellus tadpoles (Anura, Hylidae)
}

\author{
Juan Manuel Pérez-Iglesias ${ }^{\mathrm{a}, \mathrm{c}}$, Celeste Ruiz de Arcaute $^{\mathrm{a}, \mathrm{c}}$, Guillermo S. Natale ${ }^{\mathrm{b}, \mathrm{c}}$, S. Soloneski ${ }^{\mathrm{a}, \mathrm{c}}$, \\ Marcelo L. Larramendy $\mathrm{a}, \mathrm{c}$, \\ ${ }^{a}$ Cátedra de Citología, Facultad de Ciencias Naturales y Museo, Universidad Nacional de La Plata, Calle 64 No 3, B1904AMA La Plata, Argentina \\ ${ }^{\mathrm{b}}$ Centro de Investigaciones del Medio Ambiente (CIMA), Facultad de Ciencias Exactas, Universidad Nacional de La Plata, La Plata, Argentina \\ ${ }^{c}$ Consejo Nacional de Investigaciones Científicas y Técnicas (CONICET), Argentina
}

\section{A R T I C L E I N F O}

\section{Keywords:}

Endo III

Fpg

Herbicide

Imazethapyr-based formulation

Modified comet assay

Oxidative DNA damage

\begin{abstract}
A B S T R A C T
Imazethapyr (IMZT) is a selective postemergent herbicide with residual action. Available data analyzing its effects in aquatic vertebrates are scarce. In previous studies, we demonstrated that IMZT induces lesions into the DNA of Hypsiboas pulchellus tadpoles using the single-cell gel electrophoresis (SCGE) assay as a biomarker for genotoxicity. Currently, this assay can be modified by including incubation with lesion-specific endonucleases, e.g., endonuclease III (Endo III) and formamidopyrimidine-DNA glycosylase (Fpg), which detect oxidized pyrimidine and purine bases, respectively. The aim of this study was to evaluate the role of oxidative stress in the genotoxic damage in circulating blood cells of $H$. pulchellus tadpoles exposed to the IMZT-based Pivot $\mathrm{H}^{\circledR}$ formulation $\left(10.59 \%\right.$ IMZT) at a concentration equivalent to $25 \%$ of the $\mathrm{LC}_{50}(96 \mathrm{~h})$ value $(0.39 \mathrm{mg} / \mathrm{L} \mathrm{IMZT})$ during 48 and 96 h. Our results demonstrate that the herbicide induces oxidative DNA damage on $H$. pulchellus tadpoles at purines bases but not at pyrimidines. Our findings represent the first evidence of oxidative damage caused by IMZT on anuran DNA using the alkaline restriction enzyme-modified SCGE assay.
\end{abstract}

\section{Introduction}

Imazethapyr (IMZT) [5-ethyl-2-(4-isopropyl-4-methyl-5-oxo-4,5-dihydroimidazol-1H-2-yl) nicotinicacid] is a member of the imidazolinone herbicides used to control grasses, broadleaved weeds, and others in a variety of crops and noncrop situations (MacBean, 2012). IMZT has been classified as a slightly toxic compound (Class III) by the U.S. Environmental Protection Agency (USEPA, 1989), and the European Union (PPDB, 2014) has classified the herbicide as a dangerous compound for the environment and has reported IMZT as a harmful irritant for the respiratory track, skin, and eyes. Though very little is known about its toxicity in nontarget organisms. When IMZT was administered orally, low or moderate acute toxicity was reported in rats (USEPA, 1989). Using algae and aquatic invertebrates, low levels of toxicity have been reported. When aquatic plants were employed as targets, e.g., Lemna gibba, high acute levels of toxicity were observed (Maki and Johnson, 1976; USEPA, 2000). Among terrestrial invertebrates, insects such as honey bees and annelids such as earth worms have been reported to have extremely high sensitivity and low sensitivity to IMZT, respectively (USEPA, 2000). So far, the levels of acute toxicity exerted by the herbicide have not been found to be acutely toxic for fish, including channel catfish, bluegill, and rainbow trout (Kegley et al., 2014, 2016; PPDB, 2014; USEPA, 2000). Nevertheless, Moraes et al. (2011) reported disorders in oxidative stress parameters in liver cells of the common carp Cyprinus carpio after exposure to both the active ingredient IMZT and to imazapic-based commercial herbicide formulations.

Overall, very little is known about the genotoxic information of IMZT. Genotoxic studies of IMZT are scarce and contradictory. Whereas IMZT did not induce chromosomal aberrations in rat bone marrow cells, both negative and positive results have been reported for $\mathrm{CHO}$ cells with and without metabolic activation, respectively (USEPA, j). Furthermore, several studies employing the conventional alkaline version of the comet assay have shown that IMZT is genotoxic to some nontarget organisms, i.e., bacteria Salmonella typhimurium and Escherichia coli (USEPA, 1989) and plants such as Allium cepa (Liman et al., 2015) as well as mammalian exposed in vitro cells (Soloneski et al., 2017). Recently, we demonstrated for the first time that the herbicide jeopardizes anuran amphibian Hypsiboas pulchellus tadpoles by inducing micronuclei induction and DNA primary damage evaluated the SCGE assay (Pérez-Iglesias et al., 2015). We observed that IMZT is able to induce acute toxic and genotoxic effects on the species, including mortality as the end point for lethality and frequency of micronuclei and other nuclear abnor-

\footnotetext{
* Corresponding author at: Cátedra de Citología, Facultad de Ciencias Naturales y Museo, Universidad Nacional de La Plata, Calle 64 No 3, B1904AMA La Plata, Argentina. Email address: marcelo.larramendy@gmail.com (M.L. Larramendy)
} 
malities as well as DNA single-strand breaks as end points for genotoxicity (Pérez-Iglesias et al., 2015).

The single cell gel electrophoresis (SCGE) bioassay, also called the comet assay, is one of the most widely used methods to detect the genotoxic capability of xenobiotics both in vivo and in vitro since it is simple, fast, specific, and sensitive. The methodology in its alkaline or neutral version, detects a variety of DNA lesions at the single-cell level, including both single- and double-strand breaks as well as alkali-labile lesions (Azqueta and Collins, 2013; Collins et al., 2014). However, when nucleoids are digested with lesion-specific endonucleases, restriction enzymes will induce DNA breaks at the damage sites they recognize, and thus the breaks can be measured by the comet assay. Thus, different types of DNA lesions can be detected by using different lesion-specific enzymes. To date, the endonucleases most commonly used in this way are the bacterial enzymes endonuclease III (Endo III, also known as $\mathrm{Nth}$ ) and formamidopyrimidine DNA-glycosylase (Fpg). Endo III recognizes oxidized pyrimidines, including thymine glycol and uracil glycol (Azqueta and Collins, 2013; Azqueta et al., 2014). The glycosylase Fpg recognizes and removes a several oxidized purines from damaged DNA such as 8-oxo-7,8-dihydroguanine (8-oxo-Gua), 2,6 diamino-4-hydroxy-5-formamidopyrimidine (FapyGua), and 4,6-diamino-5-formamidopyridine (FapyAde). The AP lyase activity of the Fpg leaves an AP sites which can be detectable by the comet assay (Azqueta and Collins, 2013; Azqueta et al., 2014). Thus, the modified methodology has be recommended for use as a sensitive biomarker to measure oxidative DNA damage in genotoxicity studies (Collins and Azqueta, 2012; Collins et al., 1996; Kushwaha et al., 2011; Wong et al., 2005).

In a previous study using the alkaline version of the SCGE assay, we demonstrated that Pivot $\mathrm{H}^{\circledR}$, an IMZT-based herbicide commercial formulation, induces genetic damage in blood cells of Hypsiboas pulchellus tadpoles (Pérez-Iglesias et al., 2015). To assess the role of oxidative DNA damage in IMZT-induced genotoxicity, in the current study we used two restriction enzymes, namely, Endo III and Fpg, in combination with the SCGE assay in circulating blood cells of $H$. pulchellus tadpoles exposed in vivo to Pivot $\mathrm{H}^{\circledR}$ (10.59\% IMZT).

\section{Materials and methods}

\subsection{Chemicals}

Pivot $\mathrm{H}^{\circledR}$ (10.59\% IMZT, CAS 81335-77-5) was purchased from BASF Argentina S.A. $\mathrm{K}_{2} \mathrm{Cr}_{2} \mathrm{O}_{7}\left[\mathrm{Cr}_{(\mathrm{VI})}\right]$ (CAS 7778-50-9) was obtained from Merck KGaA (Darmstadt, Germany) and hydrogen peroxide $\left(\mathrm{H}_{2} \mathrm{O}_{2}\right.$, CAS 7722-84-1) was purchased from Merck KGaA (Darmstadt, Germany). Endo III and Fpg were purchased from New England Biolabs ${ }^{\circledR}$ Inc. (Ipswich, MA). All other chemicals and solvents of analytical grade for the comet assay were purchased from Sigma Chemical Co.

\subsection{Quality control}

Determination of the concentration levels of IMZT in the test solutions was performed by QV Chem Laboratory (La Plata, Buenos Aires, Argentina) according to U.S. Geological Survey Report 01-4134 (Furlong et al., 2011). IMZT levels were analyzed by high performance liquid chromatography. Active ingredient samples from quadruplicated test solutions $(0.39 \mathrm{mg} / \mathrm{L})$ correspond to values obtained immediately after preparation $(0 \mathrm{~h})$ and $24 \mathrm{~h}$ thereafter. The detection limit for IMZT was $0.5 \mu \mathrm{g} / \mathrm{L}$.

\subsection{Test organisms}

H. pulchellus is an anuran arboreal amphibian species from the Hylidae family. This species has an extensive distribution in the Neotropical America and is an abundant species in the Pampasic region of Argentina (Cei, 1980). Its natural habitats are subtropical or tropical dry lowland grasslands, subtropical or tropical seasonally wet or flooded lowland grasslands, intermittent fresh water lakes, intermittent fresh water marshes, and pasturelands (Kwet et al., 2004). This species lays its eggs in masses attached to the submerged stems of aquatic plants, and it is easy to handle and acclimate to laboratory conditions as previously stressed (Pérez-Iglesias et al., 2014, 2015; Ruiz de Arcaute et al., 2014).

All organisms used for this study were collected from a temporary and unpolluted pond away from agricultural areas, in the vicinity of La Plata City $\left(35^{\circ} 10^{\prime} \mathrm{S}, 57^{\circ} 51^{\prime} \mathrm{W}\right.$; Buenos Aires Province, Argentina), at late cleavage stage (GS) 9 according to Gosner's (Gosner, 1960) classification. Hatchlings were transported to the laboratory and then acclimatized to a $16 / 8 \mathrm{~h}$ light/dark cycles in aquaria at $25{ }^{\circ} \mathrm{C}$ with dechlorinated tap water with artificial aeration. The physical and chemical parameters of the water were as follows: temperature, $25.0 \pm 1{ }^{\circ} \mathrm{C} ; \mathrm{pH}$ $8.0 \pm 0.1$; dissolved oxygen, $6.3 \pm 0.3 \mathrm{mg} / \mathrm{L}$; conductivity, $663 \pm 15.0 \mu \mathrm{S} /$ $\mathrm{cm}$; hardness, $181 \pm 35.0 \mathrm{mg} / \mathrm{L} \mathrm{CaCO}_{3}$. Commercially available fish food (Tetra Min ${ }^{\circledR}$, TetraWerke, Germany) as a food source was supplied twice a week until individuals reached development stage 36 (GS36; range 35-37) according to Gosner (1960). Afterwards, individuals were randomly deposited in test chambers according to the experimental design. Hatches were collected with the permission of the Flora and Fauna Direction from the Buenos Aires Province (Buenos Aires, Argentina; code 22500-22339/13), and experimental procedures were approved by the Ethical Committee of the National University of La Plata (code 11/ N754).

\subsection{Experimental design}

In vivo exposure to $0.39 \mathrm{mg} / \mathrm{L}$ IMZT was performed for 48 and $96 \mathrm{~h}$ according to the procedures described in detail elsewhere for $\mathrm{H}$. pulchellus tadpoles (Pérez-Iglesias et al., 2014, 2015; Ruiz de Arcaute et al., 2014). Briefly, experiments were performed using five GS36 tadpoles for each experimental point, maintained in a $500 \mathrm{~mL}$ glass container and exposed in acute bioassay to concentration of IMZT equivalent to $25 \%$ of the corresponding LC50 ( $96 \mathrm{~h}$ ) value. All test solutions were prepared immediately before use and replaced every $24 \mathrm{~h}$. Tadpoles were not fed throughout the experiment. Experiments were performed in quadruplicate and run simultaneously. $H$. pulchellus tadpoles were sacrificed according to the American Society of Ichthyologists and Herpetologists criteria (ASIH, 2004). Blood samples for comet assay were obtained at 48 and $96 \mathrm{~h}$ after initial treatment. For positive controls, aliquots $(15 \mu \mathrm{L})$ of blood cells were obtained, and the cells were immersed in low melting point agarose. After solidification of the second agarose layer, the coverslips were removed, and slides were treated with $50 \mu \mathrm{M} \mathrm{H}_{2} \mathrm{O}_{2}$, for 5 min, at $4{ }^{\circ} \mathrm{C}$.

\subsection{Enzyme-modified alkaline single cell gel electrophoresis assay}

The endonuclease-modified comet assay described by Collins et al. (1996) and Guilherme et al. (2012) was employed with minor modifications. Briefly, immediately after lysis, the slides were washed three times in an enzyme buffer ( $40 \mathrm{mM}$ HEPES, $0.1 \mathrm{M} \mathrm{KCl,} 0.5 \mathrm{mM}$ EDTA, $0.2 \mathrm{mg} / \mathrm{mL}$ bovine serum albumin, $\mathrm{pH}$ 8.0) for $5 \mathrm{~min}$ each at room temperature. Then they were drained and exposed to Endo III or Fpg diluted $1: 1000$ or $1: 3000$, respectively, following recommendation of the enzymes supplier. Briefly, slides were incubated with $50 \mu \mathrm{L}$ of Endo III (0.5 U) or Fpg (0.13 U) as suggested elsewhere (Collins, 2004; Collins et al., 1993). Control cells were treated with $50 \mu \mathrm{L}$ of the corresponding enzyme buffer. After incubation for 30 or $45 \mathrm{~min}$ at $37{ }^{\circ} \mathrm{C}$ under a humid atmosphere for Endo III- or Fpg-exposed samples, respectively, the slides were processed following conventional alkaline SCGE protocol as described previously (Soloneski et al., 2016). Control cells were treated with $50 \mu \mathrm{L}$ of the corresponding enzyme buffer. After the enzyme restriction exposure, coverslips were removed and the slides placed on a horizontal electrophoresis unit with an electrophoresis buffer $(1 \mathrm{mM} \mathrm{Na} \mathrm{FDTA} \mathrm{E}, 300 \mathrm{mM} \mathrm{NaOH})$ for $10 \mathrm{~min}$ at $4{ }^{\circ} \mathrm{C}$ to allow the cellular DNA to unwind, followed by electrophoresis in the same buffer and temperature for $40 \mathrm{~min}$ at $25 \mathrm{~V}$ and $250 \mathrm{~mA}$. All the steps listed above were performed under yellow light or in the dark to prevent additional DNA damage. Slides were then neutralized $(0.4 \mathrm{M}$ Tris, pH 7.5) and stained with 4',6-diamino-2-phenylindole (Vectashield Mounting Medium H1200; Vector Laboratories, Burlingame, CA). Slides 
damage was quantified by the length of DNA migration, which was visually determined in 100 randomly selected and nonoverlapping cells (Azqueta et al., 2011; Collins, 2004; Collins et al., 1995; Kobayashi et al., 1995). DNA damage was classified in five classes (0-I, undamaged; II, minimum damage; III, medium damage; IV, maximum damage), as suggested previously (Cavaş and Könen, 2007). Data are expressed as the mean number of damaged cells (sum of Classes II, III, and IV) and the mean comet score for each treatment group. The genetic damage index (GDI) was calculated for each test compound following Pitarque et al. (1999) using the formula GDI $=[\mathrm{I}$ (I) +2 (II) +3 (III) +4 (IV) $/ N$ (0-IV)], where $0-$ IV represent the nucleoid type, and $N_{0}-N_{\text {IV }}$ represent the total number of nucleoids scored. Afterward, oxidative DNA damage (OD) was obtained for each treatment using the formula OD $=[(\% \mathrm{GDI}$ buffer + \%GDI enzyme + \%GDI herbicide $)-(\%$ GDI buffer + \%GDI herbicide)], as indicated previously (Collins and Azqueta, 2012; Domijan et al., 2006; Mikloš et al., 2009; Soloneski et al., 2016).

\subsection{Statistical analysis}

To estimate the effects of the treatments (herbicide exposure, negative and positive control) on each group (with and without restriction enzymes), an one-way analysis of variance with Tukey's test was performed (Zar, 2010) using the GDI as a variable. To compare OD produced by IMZT in each enzyme (respect buffer enzyme), a $t$-test for the difference of means with equal variances was performed; previously, a test of homogeneity of variances was performed (Zar, 2010). The level of significance chosen was $\alpha=0.05$ for all tests, unless indicated otherwise.

\section{Results}

Results of chemical analyses showed no significant changes $(\mathrm{P}>0.05)$ in the concentration of the toxicant in treatments during the $24 \mathrm{~h}$ interval renewals of the testing solutions (concentration range, $98 \pm 5 \%$ recovery).

Data from the Endo III- and Fpg-modified SCGE assay obtained in circulating blood cells of $H$. pulchellus tadpoles exposed in vivo to $0.39 \mathrm{mg} / \mathrm{L}$ IMZT for 48 and $96 \mathrm{~h}$ are presented in Table 1 , and the levels of net oxidative DNA damage are depicted in Fig. 1. Verification of the ability of Endo III and Fpg to recognize oxidized bases in our test system was repeated incubating cells with $50 \mu \mathrm{M} \mathrm{H}_{2} \mathrm{O}_{2}$ and employed as positive control. $\mathrm{H}_{2} \mathrm{O}_{2}$ treatment induced an enhancement in the frequency of damaged cells, the GDI, and OD values in enzyme buffer treated-cells exposed to Endo III $(p<0.01)$ and Fpg $(p<0.001)$ (Table 1; Fig. 1).

The treatment with Fpg produced a significant increase in DNA damage as well as of the GDI in tadpoles blood cells exposed to the IMZT-based herbicide formulation Pivot $\mathrm{H}^{\circledR}$ compared with cells without treatment with the enzyme at both times of exposure (enzyme buffer-treated cells; $p<0.05$; Table 1; Fig. 1). Particularly, differences in DNA damage in tadpoles exposed to Pivot $\mathrm{H}^{\circledR}$ are due to an increase on type III and IV nucleoids after 48 y $96 \mathrm{~h}$, respectively $(p<0.05$; Table 1$)$ when comparing cells treated with Fpg-enzyme with cells without treatment with the enzyme. On the other hand, post-treatment with Endo III did not induce any difference in the level of DNA damage and GDI in cells exposed to Pivot $\mathrm{H}^{\circledR}$ compared to enzyme buffer treated-cells ( $p>0.05$; Table 1; Fig. 1).

\section{Discussion}

The common tree frog, also called the Montevideo tree frog, $H$. pulchellus, is an arboreal anuran species in the family Hylidae. The species was recently reported as threatened by agricultural water pollution (specifically pesticide runoff) in the central inner part of Argentina (Kwet et al., 2004). Previous studies have stressed that the tested hylidae frog tadpoles can be considered suitable reference organisms in the risk assessment of lethal and sublethal effects induced by several emerging pollutants, including agrochemicals. Among them, the chemotherapeutic cyclophosphamide (Lajmanovich et al., 2005), the herbicide glufosinate ammonium (Peltzer et al., 2013), the insecticides fenitrothion
(Agostini et al., 2013; Lajmanovich et al., 2005), imidacloprid (Ruiz de Arcaute et al., 2014), and the imidacloprid-based insecticide formulation Glacoxan Imida ${ }^{\circledR}$ (Pérez-Iglesias et al., 2014) can be included.

We recently employed $H$. pulchellus as a target species to evaluate the acute lethal and sublethal effects of the herbicide imazethapyr-based commercial formulation Pivot $\mathrm{H}^{\circledR}$ (Pérez-Iglesias et al., 2015). Whereas mortality was used as the end point for lethality, frequency of micronuclei and other nuclear abnormalities as well as DNA single-strand breaks evaluated by the SCGE assay were employed to test genotoxicity. Behavioral, growth, developmental, and morphological abnormalities were also employed as sublethal end points. Mortality studies revealed equivalent $\mathrm{LC}_{50}(96 \mathrm{~h})$ values of 1.49 and $1.55 \mathrm{mg} / \mathrm{L}$ IMZT for Gosner stages 25 and 36, respectively. Behavioral changes, i.e., irregular swimming and immobility, as well as a decreased frequency of keratodonts were observed. The herbicide increased the frequency of micronuclei in circulating erythrocytes of tadpoles exposed for $48 \mathrm{~h}$ to $1.17 \mathrm{mg} / \mathrm{L}$ IMZT. However, regardless of the concentration of the herbicide assayed, an enhanced frequency of micronuclei was observed in tadpoles exposed for $96 \mathrm{~h}$ within the $0.39-1.17 \mathrm{mg} / \mathrm{L}$ IMZT range. Our results also demonstrated that the herbicide was able to induce other nuclear abnormalities, i.e., blebbed and notched nuclei, only when tadpoles were exposed for $96 \mathrm{~h}$. In addition, we observed that exposure to IMZT within the $0.39-1.17 \mathrm{mg} / \mathrm{L}$ range increased the genetic damage index in treatments lasting for both 48 and $96 \mathrm{~h}$ (Pérez-Iglesias et al., 2015). To the best of our knowledge, this study represents the first evidence of acute lethal and sublethal effects exerted by IMZT on amphibians and highlights the ability of this herbicide to jeopardize exposed nontarget living species, at least $H$. pulchellus tadpoles (Pérez-Iglesias et al., 2015).

Despite the battery of end points assessed on $H$. pulchellus in our previous study (Pérez-Iglesias et al., 2015), further questions regarding the type of genetic damage that this compound is able to introduce into DNA molecules are still unanswered, since this aspect has yet to be covered. Our current results clearly demonstrate exposure to $0.39 \mathrm{mg} / \mathrm{L}$ IMZT is able to introduce damage into the DNA of circulating blood cells of $H$. pulchellus tadpoles. To elucidate a possible mechanism of IMZT-induced DNA damage, we employed two restriction enzymes in the current study, namely, Endo III and Fpg, in combination with the SCGE assay, to reveal the presence of oxidized pyrimidines and purines, respectively, as a result of herbicide-induced oxidative stress in circulating blood cells of $H$. pulchellus tadpoles exposed in vivo to Pivot $\mathrm{H}^{\circledR}$.

Oxidative DNA damage can be measured to assess the genotoxic/ carcinogenic potential of environmental chemicals. A direct assessment of oxidative damage may provide important information about the molecular effects of oxidative stress on DNA (Collins et al., 1996). Currently employed methods to measure oxidative DNA damage have certain limitations, such as artifactual DNA oxidation during sample isolation and DNA hydrolysis during high-performance liquid chromatography with electrochemical detection, gas chromatography-mass spectrometry, or HPLC-tandem mass spectrometry analyses, and DNA oxidation assays with antibodies are only semiquantitative and thus may produce misleading results (Collins, 2004; Gedik and Collins, 2005; Halliwell, 2000). In contrast, the SCGE assay is one of the most promising methods for detecting the genotoxic potential of chemicals because it is simple, fast, specific, and sensitive. Furthermore, the assay requires only small samples and can directly quantify the amount of oxidative DNA damage (Collins, 2004; Tice et al., 2000). Furthermore, lesion-specific endonucleases, such as Fpg or Endo III, also known as Nth, can recognize specific oxidatively damaged bases and create additional breaks to aid in the detection of oxidative DNA damage in a modified SCGE assay (Collins, 2004; Collins and Azqueta, 2012; Smith et al., 2006). Fpg specifically recognizes the number of oxidized purine bases and other ring-opened purines, whereas Endo III recognizes oxidized pyrimidines (Collins, 2004; Collins and Azqueta, 2012; Smith et al., 2006). We could emphasize the importance of using the modified SCGE technique to assess oxidative damage introduced into the DNA of amphibians as a consequence of pesticide exposure. Our observations reveal that treatment with both Endo III and Fpg buffers induce an enhancement in the frequency of DNA damage 
Table 1

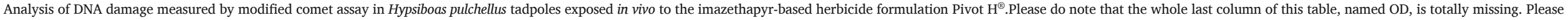
do use the attached doccument for addressing this mistake.

\begin{tabular}{|c|c|c|c|c|c|c|c|c|c|c|}
\hline Compound & $\begin{array}{l}\text { Exposure time } \\
\text { (h) }\end{array}$ & Treatment & $\begin{array}{l}\text { No. animals } \\
\text { analyzed }\end{array}$ & $\begin{array}{l}\text { No. of nucleoids } \\
\text { analyzed }\end{array}$ & Proportion & maged nucle & $(\%)^{\mathrm{a}}$ & & $\begin{array}{l}\% \text { of damaged nucleoids } \\
\text { (II + III + IV) }\end{array}$ & $\mathrm{GDI} \pm \mathrm{SE}^{\mathrm{b}, \mathrm{c}}$ \\
\hline & & & & & $\begin{array}{l}\text { Type } \\
0+\mathrm{I}\end{array}$ & Type II & Type III & Type IV & & \\
\hline \multirow[t]{5}{*}{ Control } & 48 & Negative & 10 & 1128 & 70.90 & 15.47 & 12.06 & 1.57 & 28.74 & $1.13 \pm 0.13$ \\
\hline & & $\begin{array}{l}\text { Buffer Endo } \\
\text { III }\end{array}$ & 9 & 1049 & 59.10 & 24.12 & 15.44 & 1.34 & 40.57 & $1.42 \pm 0.18$ \\
\hline & & Endo III & 8 & 927 & 57.39 & $35.50^{\# \# \#}$ & 12.62 & 1.25 & 43.06 & $1.49 \pm 0.09^{\#}$ \\
\hline & & Buffer Fpg & 10 & 959 & 60.58 & 23.67 & 13.24 & 2.50 & 40.14 & $1.48 \pm 0.08^{\#}$ \\
\hline & & Fpg & 10 & 1051 & $54.81^{\#}$ & $25.02^{\#}$ & 18.08 & 2.09 & $44.89^{\#}$ & $1.55 \pm 0.04^{\# \#}$ \\
\hline \multirow[t]{5}{*}{ Pivot $\mathrm{H}^{\circledast}$} & & $0.39 \mathrm{mg} / \mathrm{L}$ & 9 & 914 & 46.61 & 38.18 & 14.00 & 1.20 & 52.62 & $1.54 \pm 0.12^{* *}$ \\
\hline & & $\begin{array}{l}\text { Buffer Endo } \\
\text { III }\end{array}$ & 8 & 806 & 47.52 & 37.84 & 13.65 & 0.99 & 52.44 & $1.63 \pm 0.05$ \\
\hline & & Endo III & 9 & 941 & 45.17 & 37.62 & 16.26 & 0.95 & 54.62 & $1.66 \pm 0.08$ \\
\hline & & Buffer Fpg & 9 & 988 & 50.51 & 30.77 & 17.41 & 1.32 & 48.83 & $1.62 \pm 0.11$ \\
\hline & & Fpg & 9 & 983 & $29.91^{\#, \&}$ & 40.18 & $27.06^{\#, \&}$ & 2.85 & $69.94^{\#, \&}$ & $1.98 \pm 0.12^{\#, \&}$ \\
\hline \multirow[t]{5}{*}{ Control } & 96 & Negative & 9 & 972 & 73.42 & 17.72 & 7.38 & 1.48 & 26.23 & $1.12 \pm 0.07$ \\
\hline & & $\begin{array}{l}\text { Buffer Endo } \\
\text { III }\end{array}$ & 9 & 929 & 70.49 & 25.55 & 7.11 & 1.33 & 29.55 & $1.17 \pm 0.08$ \\
\hline & & Endo III & 9 & 995 & 67.64 & $26.13^{\#}$ & 5.53 & 0.70 & 31.85 & $1.19 \pm 0.08$ \\
\hline & & Buffer Fpg & 9 & 984 & $55.89^{\# \# \#}$ & $31.81^{\# \#}$ & 10.36 & 1.93 & $44.31^{\# \#}$ & $1.49 \pm 0.07^{\# \#}$ \\
\hline & & Fpg & 9 & 1006 & $49.20^{\# \# \#}$ & $42.44^{\# \# \#}$ & 12.22 & 1.88 & $50.64^{\# \# \#}$ & $1.57 \pm 0.10^{\# \# \#}$ \\
\hline \multirow[t]{5}{*}{ Pivot $\mathrm{H}^{\circledR}$} & & $0.39 \mathrm{mg} / \mathrm{L}$ & 10 & 1105 & 50.95 & 31.95 & 15.29 & 1.81 & 49.55 & $1.56 \pm 0.14^{* *}$ \\
\hline & & $\begin{array}{l}\text { Buffer Endo } \\
\text { III }\end{array}$ & 9 & 1039 & 50.79 & 36.84 & 10.31 & 2.06 & 48.77 & $1.52 \pm 0.08$ \\
\hline & & Endo III & 10 & 1102 & 49.37 & 33.03 & 14.25 & 3.36 & 50.67 & $1.64 \pm 0.13$ \\
\hline & & Buffer Fpg & 9 & 991 & 42.38 & 35.12 & 19.27 & 3.23 & 57.17 & $1.78 \pm 0.12$ \\
\hline & & Fpg & 9 & 930 & $30.97^{\#, \&}$ & 36.77 & 24.52 & $7.74^{\# \#, \&}$ & $69.22^{\#, \&}$ & $2.08 \pm 0.08^{\# \#, \&}$ \\
\hline \multirow{5}{*}{$\begin{array}{l}\text { Positive } \\
\text { control }^{\mathrm{e}}\end{array}$} & & $50 \mu \mathrm{M}$ & 10 & 1000 & 29.94 & 38.62 & 29.61 & 1.84 & 72.14 & $2.00 \pm 0.09^{* * *}$ \\
\hline & & $\begin{array}{l}\text { Buffer Endo } \\
\text { III }\end{array}$ & 10 & 1160 & 29.18 & 32.29 & 19.51 & 9.01 & 65.56 & $1.93 \pm 0.16$ \\
\hline & & Endo III & 10 & 993 & $15.11^{\#}$ & $29.47^{\#}$ & 41.81 & $13.60^{\#}$ & $79.32^{\#, 8 \&}$ & $2.53 \pm 0.14^{\#, 8 \&}$ \\
\hline & & Buffer Fpg & 10 & 1161 & 35.25 & 35.46 & 22.40 & 6.89 & 64.37 & $1.99 \pm 0.10$ \\
\hline & & Fpg & 10 & 991 & $12.62^{\# \#}$ & $15.48^{\# \#}$ & 29.35 & $42.56^{\# \# \#}$ & $86.07^{\# \#, \& \& \& \&}$ & $3.05 \pm 0.17^{\# \# \#, \& \& \& \&}$ \\
\hline
\end{tabular}

\section{*P< $<0.05$.}

DNA damage (OD).

a I-IV indicate grades of DNA damage as mean values of pooled data from three independent experiments.

b Results are presented as mean values of pooled data from three independent experiments \pm S.E. of the mean.

c Genetic damage index (GDI).

e Hydrogen peroxide $\left(\mathrm{H}_{2} \mathrm{O}_{2}, 50 \mu \mathrm{M}\right)$ was used as positive control.

** $\mathrm{P}<0.01$ compared with negative control value.

* $\mathrm{P}<0.001$ compared with negative control value.

* $\mathrm{P}<0.05$ compared with respective group control.

\# $\mathrm{P}<0.01$ compared with respective group control.

\#\# $\mathrm{P}<0.001$ compared with respective group control.

\& $\mathrm{P}<0.05$ compared with respective buffer-enzyme.

\& $\mathrm{P}<0.01$ compared with respective buffer-enzyme.

\&\&\& $\mathrm{P}<0.001$ compared with respective buffer-enzyme. 


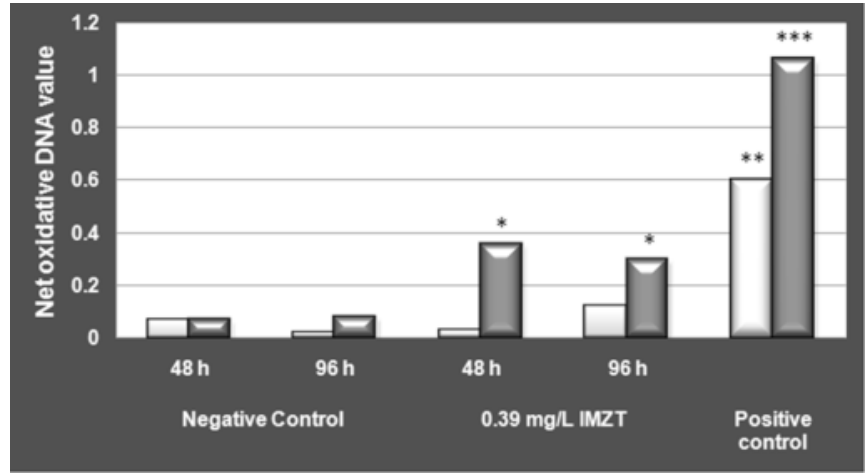

Fig. 1. Imazethapyr-based commercial formulation herbicide Pivot $\mathrm{H}^{\circledR}$-induced DNA damage measured by modified comet assay using Endo III (light gray bars) and Fpg (dark gray bars) enzymes in circulating blood cells of Hypsiboas pulchellus tadpoles exposed in vivo. The net oxidative DNA damage was calculated as the difference between the score obtained after incubation with the respective enzyme or with the buffer. Hydrogen peroxide $(50 \mu \mathrm{M})$ was used as positive control, respectively. *, $P<0.05$; **, $P<0.01$; *** $P<0.001$; significant differences with respect to control values.

duce lesions into cellular DNA, and thus increasing the length of the nucleoids (Collins and Azqueta, 2012; Demir et al., 2014; Soloneski et al., 2016, 2017). Furthermore, our results demonstrate that the modified SCGE assay using Fpg, but not Endo III, turned out to be highly sensitive and effective in detecting genetic oxidative damage introduced into the DNA of circulating blood cells of $H$. pulchellus tadpoles by the herbicide IMZT-based commercial formulation Pivot $\mathrm{H}^{\circledast}$ at purine bases, but not pyrimidines. So far, only Calevro et al. (1998) have analyzed the extent of oxidative DNA damage employing the Fpg-modified alkaline comet assay in amphibians, using primary brain cell cultures from the newt Pleurodeles walt exposed to the cadmium(II). Although the authors demonstrated that cadmium(II) is not able to induce oxidative DNA base modifications in larval brain cells, they show that the agent has the capability to generate DNA strand breaks and to interfere with the repair of xenobiotic-induced oxidative damage (Calevro et al., 1998). Thus, to the best of our knowledge, our current findings represent the first evidence of DNA oxidative damage caused by exposure to a xenobiotic, such as the IMZT-based commercial herbicide formulation Pivot $\mathrm{H}^{\circledR}$, revealed using the restriction enzyme-modified alkaline SCGE assay not only for the Neotropical anuran species $H$. pulchellus, but for amphibians worldwide.

Finally, our observations corroborate that the IMZT-based herbicide formulation Pivot $\mathrm{H}^{\circledR}$ exerts genotoxic effects (Liman et al., 2015; Pérez-Iglesias et al., 2015; USEPA, 1989) and acts as an oxidizing agent, as suggested previously by Moraes et al. (2011), on nontarget organisms such as C. carpio. As remarked by Collins (2004), this modified SCGE technique can be used in combination with biosensors for contamination of the environment with genotoxins, at least in aquatic vertebrates.

Although the IMZT treatment in this study includes only one concentration, it represents a relatively high end of the threshold value of $14 \mu \mathrm{g} / \mathrm{L}$ IMZT found in the surface water of the Azul River basin (Buenos Aires, Argentina) reported by Peluso et al. (2008), even considering the recommended application field ratios of $100-150 \mathrm{~g}$ a.i./ ha reported for Argentina (Bindraban et al., 2009; CASAFE, 2011). It should be mentioned that the IMZT concentrations found in Argentinean crop production areas is nearly 7.6 times higher than the highest concentration reported for surface water in United States (Mattice et al., 2011) or even 51.8 and 40.0 times higher than the highest concentration reported for Brazilian drinking and surface waters, respectively (Souza Caldas et al., 2011). Thus, the concentration of IMZT employed in this investigation would be expected to be almost improbable in the environment, perhaps observed only when specific events occurred (e.g., direct application, drainage into ditches, or accidental discharge). Although, we cannot rule out that amphibian populations and also occupationally exposed human workers could be exposed accidentally to these agrochemicals at this range of concentrations. However, our observations highlight that the methodology employed in our study can be used as a sensitive and informative biosensor for contamina- tion of the environment with genotoxins for aquatic vertebrates, at least H. pulchellus tadpoles.

\section{Conflict of interest statement}

The authors declare that there are no conflicts of interest.

\section{Acknowledgements}

This study was supported by grants from the National University of La Plata (Grants 11/N746 and 11/N817), the National Council for Scientific and Technological Research (CONICET, PIP Number 0344), and the National Agency of Scientific and Technological Promotion (PICT 2015 Number 3059) from Argentina.

\section{References}

Agostini M.G. Natale G.S. Ronco A.E. 2010. Lethal and sublethal effects of cypermethrin to Hypsiboas pulchellus tadpoles Ecotoxicology 19 1545-1550

Agostini, M.G., Kacoliris, F., Demetrio, P., Natale, G.S., Bonetto, C., Ronco, A.E., 2013. Abnormalities in amphibian populations inhabiting agroecosystems in northeastern Buenos Aires Province, Argentina. Dis. Aquat. Organ. 104, 163-171.

ASIH, 2004. American Society of ichthyologists and herpetologists. Guidelines for Use of Live Amphibians and Reptiles in Field and Laboratory Research. Herpetological Animal Care and Use Committee of the ASIH, Washington,DC.

Azqueta, A., Collins, A.R., 2013. The essential comet assay: a comprehensive guide to measuring DNA damage and repair. Arch. Toxicol. 87, 949-968.

Azqueta, A., Meier, S., Priestley, C., Gutzkow, K.B., Brunborg, G., Sallette, J., Soussaline, F., Collins, A., 2011. The influence of scoring method on variability in results obtained with the comet assay. Mutagenesis 26, 393-399.

Azqueta, A., Slyskova, J., Langie, S.A.S., Gaivão, I.O., Collins, A., 2014. Comet assay to measure DNA repair: approach and applications. Front. Genet. 5, 1-8.

Bindraban, P.S., Franke, A.C., Ferraro, D.O., Ghersa, C.M., Lotz, L.A.P., Nepomuceno, A., Smulders, M.J.M., van de Wiel, C.C.M., 2009. GM-Related Sustainability: Agroecological Impacts, Risks and Opportunities of Soy Production in Argentina and Brazil. Plant Research International, Wageningen UR, Netherlands.

Calevro, F., Beyersmann, D., Hartwig, A., 1998. Effect of cadmium(II) on the extent of oxidative DNA damage in primary brain cell cultures from Pleurodeles larvae. Toxicol. Lett. 94, 217-225.

CASAFE, 2011. Guía de Productos Fitosanitarios para la Republica Argentina. Buenos Aires, Argentina.

Cavaş, T., Könen, S., 2007. Detection of cytogenetic and DNA damage in peripheral erythrocytes of goldfish (Carassius auratus) exposed to a glyphosate formulation using the micronucleus test and the comet assay. Mutagenesis 22, 263-268.

Cei, J.M., 1980. Amphibians of Argentina. Monit. Zool. Ital. N. Ser. Monogr. 2, 1-609.

Collins, A., Koppen, G., Valdiglesias, V., Dusinska, M., Kruszewski, M., Møler, P., Rojas, E., Dhawan, A., Benzie, I., Coskun, E., Moretti, M., Speit, G., Bonassi, S., 2014. The comet assay as a tool for human biomonitoring studies: the ComNet Project. Mutat. Res. 759, 27-39.

Collins, A.R., 2004. The comet assay for DNA damage and repair. Mol. Biotechnol. 26, 249-261.

Collins A.R. Azqueta A. 2012. DNA repair as a biomarker in human biomonitoring studies; further applications of the comet assay Mutat. Res. 736 122-129

Collins A.R. Duthie S.J. Dobson V.L. 1993. Direct enzymic detection of endogenous oxidative base damage in human lymphocyte DNA Carcinogenesis 14 1733-1735

Collins, A.R., Ai-Guo, M., Duthie, S.J., 1995. The kinetics of repair of oxidative DNA damage (strand breaks and oxidised pyrimidines) in human cells. Mutat. Res. 336, 69-77.

Collins, A.R., Dusinská, M., Gedik, C.M., Stetina, R., 1996. Oxidative damage to DNA: do we have a reliable biomarker?. Environ. Health Perspect. 104, 465-469.

Demir, E., Akça, H., Kaya, B., Burgucu, D., Tokgün, O., Turna, F., Aksakal, S., Vales, G., Creus, A., Marcos, R., 2014. Zinc oxide nanoparticles: genotoxicity, interactions with UV-light and cell-transforming potential. J. Hazard. Mater. 264, 420-429.

Domijan, A., Zeljezic, D., Kopjar, N., Peraica, M., 2006. Standard and Fpg-modified comet assay in kidney cells of ochratoxin A- and fumonisin B1-treated rats. Toxicology 222, 53-59.

Furlong, E.T., Anderson, B.D., Werner, S.L., Soliven, P.P., Coffey, L.J., Burkhardt, M.R., 2011. Methods of analysis but the US Geological Survey National Water Quality Laboratory - Determination of pesticides in water by graphitized carbon-based solid-phase extraction and high-performance liquid chromatography/mass spectrometry. US Geological Survey Water Resources Investigations Report 01-4134. p. 73.

Gedik, C.M., Collins, A.R., 2005. Establishing the background level of base oxidation in human lymphocyte DNA: results of an interlaboratory validation study. FASEB J. $19,82-84$.

Gosner, K.L., 1960. A simplified table for staging anuran embryos and larvae with notes on identification. Herpetologica 183-190.

Guilherme, S., Santos, M.A., Barroso, C., Gaivão, I., Pacheco, M., 2012. Differential genotoxicity of RoundUp ${ }^{\circledR}$ formulation and its constituents in blood cells of fish (Anguilla anguilla): considerations on chemical interactions and DNA damaging mechanisms. Ecotoxicology 21, 1381-1390.

Halliwell, B., 2000. Why and how should we measure oxidative DNA damage in nutritional studies? How far have we come?. Am. J. Clin. Nutr. 72, 1082-1087.

Junges, C.M., Lajmanovich, R.C., Peltzer, P.M., Attademo, A.M., Bassó, A., 2010. Predator-prey interactions between Synbranchus marmoratus (Teleostei: Synbranchidae) and Hypsiboas pul- 
chellus tadpoles (Amphibia: Hylidae): Importance of lateral line in nocturnal predation and effects of fenitrothion exposure Chemosphere 81, 1233-1238.

Kegley, S.E., Hill, B.R., Orme, S., Choi, A.H., 2014. PAN Pesticide Database. Pesticide Action Network, Oakland, CA.

Kegley, S.E., Hill, B.R., Orme, S., Choi, A.H., 2016. PAN Pesticide Database. In: N.A.O. Pesticide Action Network, CA), (Ed.), 〈http:www.pesticideinfo.org $\rangle$.

Kobayashi, H., Sugiyama, C., Morikawa, Y., Hayashi, M., Sofuni, T., 1995. A comparison between manual microscopic analysis and computerized image analysis in the single cell gel electrophoresis assay. MMS Commun. 3, 103-115.

Kushwaha, S., Vikram, A., Trivedi, P.P., Jena, G.B., 2011. Alkaline, Endo III and FPG modified comet assay as biomarkers for the detection of oxidative DNA damage in rats with experimentally induced diabetes. Mutat. Res. 726, 242-250.

Kwet, A., Aquino, L., Lavilla, E., di Tada, I., 2004. Hypsiboas pulchellus. The IUCN Red List of Threatened Species. Version 2014.3. The IUCN Red List of Threatened Species Web.

Lajmanovich, R., Cabagna, M., Peltzer, P.M., Stringhini, G.A., Attademo, A.M., 2005. Micronucleus induction in erythrocytes of the Hyla pulchella tadpoles (Amphibia: Hylidae) exposed to insecticide endosulfan. Mutat. Res. 587, 67-72.

Liman, R., İbrahim, H.C., Nur, S.O., 2015. Determination of genotoxic effects of Imazethapyr herbicide in Allium cepa root cells by mitotic activity, chromosome aberration, and comet assay. Pestic. Biochem. Phys. 118, 38-42.

MacBean, C., 2012. The Pesticide Manual: A World Compendium. British Crop Protection Council, United Kingdom, Alton, Hampshire.

Maki, A.W., Johnson, H.E., 1976. The freshwater mussel (Anodonta sp.) as an indicator of environmental levels of 3-trifluoromethyl-4-nitrophenol (TFM). Investigations in Fish Control. US Fish and Wildlife Service, Upper Midwest Environmental Sciences Center.

Mattice, J.D., Smartt, A., Teubl, S., Scott, T., Norman, R.J., 2011. Pest management: weeds. Environmental implications of pesticides in rice production. AAES Res. Ser. 591, 141-153.

Mikloš, M., Gajski, G., Garaj-Vrhovac, 2009. Usage of the standard and modified comet assay in assessment of DNA damage in human lymphocytes after exposure to ionizing radiation. Radiol. Oncol. 43, 97-107.

Moraes, B.S., Clasen, B., Loro, V.L., Pretto, A., Toni, C., de Avila, L.A., Marchesan, E., de Oliveira Machado, S.L., Zanella, R., Reimche, G.B., 2011. Toxicological responses of Cyprinus carpio after exposure to a commercial herbicide containing imazethapyr and imazapic. Ecotoxicol. Environ. Safe 74, 328-335.

Peltzer, P.M., Junges, C.M., Attademo, A.M., Bassó, A., Grenón, P., Lajmanovich, R.C., 2013. Cholinesterase activities and behavioral changes in Hypsiboas pulchellus (Anura: Hylidae) tadpoles exposed to glufosinate ammonium herbicide. Ecotoxicology $22,1165-1173$.

Peluso, F., González Castelain, J., Varela, C., Usunoff, E., 2008. Evaluación preliminar del riesgo sanitario por agroquímicos en aguas del arroyo Azul, provincia de Buenos Aires. Biol. Acuát. 24, 123-130.
Pérez-Iglesias, J.M., Ruiz de Arcaute, C., Nikoloff, N., Dury, L., Soloneski, S., Natale, G.S., Larramendy, M.L., 2014. The genotoxic effects of the imidacloprid-based insecticide formulation Glacoxan Imida on Montevideo tree frog Hypsiboas pulchellus tadpoles (Anura, Hylidae). Ecotoxicol. Environ. Safe 104, 120-126.

Pérez-Iglesias, J.M., Soloneski, S., Nikoloff, N., Natale, G.S., Larramendy, M.L., 2015. Toxic and genotoxic effects of the imazethapyr-based herbicide formulation Pivot $\mathrm{H}^{\circledR}$ on montevideo tree frog Hypsiboas pulchellus tadpoles (Anura, Hylidae). Ecotoxicol. Environ. Safe 119, 15-24.

Pitarque, M., Vaglenov, A., Nosko, M., Hirvonen, A., Norppa, H., Creus, A., Marcos, R., 1999. Evaluation of DNA damage by the Comet assay in shoe workers exposed to toluene and other organic solvents. Mutat. Res. 441, 115-127.

PPDB, 2014. Imazethapyr (Ref: AC252925). Pesticide Properties Data Base.

Ruiz de Arcaute, C., Pérez-Iglesias, J.M., Nikoloff, N., Natale, G.S., Soloneski, S., Larramendy, M.L., 2014. Genotoxicity evaluation of the insecticide imidacloprid on circulating blood cells of Montevideo tree frog Hypsiboas pulchellus tadpoles (Anura, Hylidae) by comet and micronucleus bioassays. Ecol. Indic. 45, 632-639.

Smith, C.C., O'Donovan, M.R., Martin, E.A., 2006. hOGG1 recognizes oxidative damage using the comet assay with greater specificity than FPG or ENDOIII. Mutagenesis $21,185-190$.

Soloneski, S., Nikoloff, N., Larramendy, M.L., 2016. Analysis of possible genotoxicity of the herbicide flurochloridone and its commercial formulations: Endo III and Fpg alkaline comet assays in Chinese hamster ovary (CHO-K1) cells. Mutat. Res. 797, 46-52.

Soloneski, S., Ruiz de Arcaute, C., Nikoloff, N., Larramendy, M.L., 2017. Genotoxicity of the herbicide imazethapyr in mammalian cells by oxidative DNA damage evaluation using the endo III and Fpg alkaline comet assays. Environ. Sci. Pollut. Res. 24, 10292-10300.

Souza Caldas, S., Zanella, R., Primel, E.G., 2011. Risk estimate of water contamination and occurrence of pesticides in the South of Brazil. In: Kortekamp, A. (Ed.), Herbicides and Environment. InTech, Rijeka.

Tice, R.R., Agurell, E., Anderson, D., Burlinson, B., Hartmann, A., Kobayashi, H., Miyamae, Y., Rojas, E., Ryu, J.C., Sasaki, Y.F., 2000. Single cell gel/comet assay: guidelines for in vitro and in vivo genetic toxicology testing. Environ. Mol. Mutagen. 35, 206-221.

USEPA, 1999. Imazethapyr Herbicide Profile 3/89. Chemical Fact Sheet for Imazethapyr. In: U.S. EPA, (Ed.), Office of Pesticide Programs. United States Environmental Protection Agency, Washington, DC, p. 196.

USEPA, 2000. Pesticide Ecotoxicity Database (Formerly: Environmental Effects Database (EEDB)). In: U.S EPA, (Ed.), Office of Pesticide Programs. United States Environmental Protection Agency, Washington, D.C.

Wong, V.W.C., Szeto, Y.T., Collins, A.R., Benzie, I.F.F., 2005. The comet assay: a biomonitoring tool for nutraceutical research. Curr. Top. Nutr. Res. 3, 1-14.

Zar, J.H., 2010. Biostatistical Analysis. Prentice Hall, NewJersey. 